\title{
Talent in the Cold? Creative Capital and the Economic Future of the Canadian North
}

\author{
ANDREY N. PETROV ${ }^{1}$
}

(Received 18 January 2006; accepted in revised form 5 September 2007)

\begin{abstract}
The concept of the creative economy provides an alternative perspective on regional development in the Canadian North. Most studies in the economic geography of talent and creativity have focused on large metropolitan centres, but from the path-creation perspective, the creative class is no less important in the northern frontier area, where it acts as the agent of economic transformation and revitalization. I used both traditional and newly developed creative class metrics based on the four-sector model of the creative class to analyze creative capital in northern towns. Although the creative class is weak in the Canadian North, I identify a group of six leading communities that constitute the creative core of the North (Yellowknife, NT; Whitehorse, YT; Inuvik, NT; Fort Smith, NT; Smithers, BC; and Iqaluit, NU). These communities have high levels of creative capital and can compete nationally in terms of quality of place to attract the creative labor force. A dozen others could be considered lesser centres of creativity. Not surprisingly, single-industry towns in the Canadian North have the weakest creative class and therefore much less potential for regional reinvention. Some characteristics of the creative class observed in northern communities are similar to those found in metropolitan areas, but others are distinctive. In the periphery, entrepreneurship and leadership appear to be more important elements than formal education. Creativity is found to be positively associated with the aboriginality of the population. Northern communities should consider adopting policies that will stimulate the growth of creative capital by developing the education and business skills, leadership ability, entrepreneurial competency, and artistic talent of their residents.
\end{abstract}

Key words: creative class, creative capital, regional development, periphery, the Canadian North

АННОТАЦИЯ. Большинство существующих исследований по экономической географии таланта и креативности посвящены ведущим экономическим районам и крупным урбанизированным зонам. Однако, как показано в статье, креативный класс - не менее важный фактор (агент социально-экономической трансформации) и в глубоко периферийных регионах. В статье обосновывается расширительная трактовка понятия креативного класса, с включением не только лиц исключительно умственного труда, но и представителей богемы, предпринимателей и менеджеров. Известные и вновь разработанные индикаторы используются для измерения степени сформированности креативного класса и способности к привлечению и удержанию его представителей, что служит основой для предлагаемой оценки потенциала креативности в 34 городских поселениях Канадского Севера. Полученные результаты свидетельствуют, что, несмотря на общую слабость креативного класса, шесть городов Севера (Йеллоунайф, Уайтхорс, Инувик, Форт Смит, Смитерс, Икалуит), имеют высокий потенциал креативности и могут стать движущим звеном регионального «обновления». Узкоспециализированные ресурсные городки демонстрируют наименьший потенциал. Однако, лишь несколько исследованных центров конкурентоспособны в привлечении профессионалов из других районов страны. Для обеспечения устойчивого развития северных городов в будущем, необходимо кардинальная смена акцента региональной политики с индустриального и социального субсидирования на развитие человеческого потенциала через поддержку образования, художественных талантов, предпринимательской активности, и инициативы местного населения, в особенности в городах-лидерах.

Ключевые слова: креативный класс, креативный капитал, экономическое развитие, периферия, Канадский Север.

RÉSUMÉ. Le concept de l'économie de la créativité nous donne une perspective différente du développement régional du Nord canadien. La plupart des études portant sur la géographie économique propre au talent et à la créativité se concentrent sur les grands centres métropolitains. Cependant, d'après la perspective de la création, la classe créative n'est pas moins importante dans les régions pionnières du Nord, là où elle joue le rôle d'agent de transformation et de revitalisation économique. J'ai recouru aux métriques de la classe créative traditionnelle et aux métriques de la classe créative nouvellement formée reposant sur le modèle à quatre secteurs de la classe créative pour analyser le capital créatif des collectivités du Nord. Bien que la classe créative soit faible dans le Nord canadien, j' ai cerné un groupe de six collectivités principales qui constituent le noyau créatif du Nord (Yellowknife, T.N.-O.; Whitehorse, Yukon; Inuvik, T.N.-O.; Fort Smith, T.N.-O.; Smithers, C.-B.; et Iqaluit, Nunavut). Le capital créatif de ces collectivités est considérable et celles-ci peuvent livrer concurrence à l'échelle nationale en matière de qualité de l'endroit pour attirer une main-d'œuvre créatrice. Une douzaine d'autres collectivités pourraient être considérées comme des centres de créativité moins importants. Fait non surprenant, les collectivités du Nord canadien centrées sur une seule industrie ont la classe créative la plus faible et par conséquent, elles possèdent des possibilités de réinvention régionale beaucoup moins grandes.

${ }^{1}$ Department of Geography, University of Toronto, 100 St. George Street, Toronto, Ontario M5S 3G3, Canada; andreyn.petrov@ utoronto.ca

(C) The Arctic Institute of North America 
Certaines caractéristiques de la classe créative observées dans les collectivités du Nord sont semblables à celles se trouvant dans les régions métropolitaines, tandis que d'autres sont distinctes. En périphérie, l'entreprenariat et le leadership semblent prendre plus d'importance que la scolarité officielle. La créativité est positivement liée au caractère autochtone de la population. Les collectivités du Nord devraient considérer l'adoption de politiques visant à stimuler la croissance du capital créatif en mettant au point des programmes d'études et des compétences en affaires, en leadership et en entreprenariat, ainsi qu'en mettant en valeur le talent artistique des gens de la région.

Mots clés : classe créative, capital créatif, développement régional, périphérie, Nord canadien

Traduit pour la revue Arctic par Nicole Giguère.

\section{INTRODUCTION}

The importance of talent, human capital, and the creative class in economic development has spawned considerable debate in economic geography. Volumes of studies demonstrated that the quality of a region's workforce is a key determinant of that region's economic success (e.g., Glaeser, 2000; Florida, 2002a; Simon and Nardinelli, 2002). Regional development studies now commonly stress the need for regions, both urban and rural, to be open and attractive to human capital (Bollman, 1999). Some, however, argue that not only the level of skills, but also the creative ability of the labor force (or of the creative class) is a key ingredient of endogenous development in urban areas (Anderson, 1985; Florida, 2002a, b). The creative class argument, although debated by many (Glaeser, 2005; Markusen, 2006), has found support in a number of empirical studies that measured creativity and its effect on regional economic competitiveness (see Florida and Gates, 2001; Florida, 2002a, b; McGranahan and Wojan, 2007). These studies also demonstrated that quality of place (interpreted as a function of diversity and openness) represents one of the most important factors in attracting creative capital (Florida, 2002b, 2005), and hence acts as a powerful force of urban and regional economic growth and development.

The creative class is often identified as the group of individuals who are either highly educated or engaged in creative (i.e., scientific, artistic, or technological) types of activities (Florida, 2002b, 2005). Although all humans possess creativity, the distinctive feature of the creative class is that its members translate their creativity into economic returns (Florida, 2005). Richard Florida and his followers have argued that the economic prosperity of a region (or a city) is contingent on its ability to attract and retain the creative class (Florida, 2002a, b, 2005; Gertler et al., 2002). Applying Florida's ideas to Canada, the recent work by the Federation of Canadian Municipalities (FCM, 2002) and Gertler et al. (2002) measured the creative class (and the attributes for attracting it) in the Canadian context. These studies revealed the geography of the creative class in Canadian metropolitan areas and compared them to their American counterparts.

To date, creative class research has been limited to large urban areas. This preoccupation is understandable, given that large cities act as clusters of creativity; however, it does not mean that peripheral areas should be completely excluded from the creative class debate. Rather, the role and function of talent-and more broadly, of the creative class-as factors of endogenous development in noncentral regions must be closely considered. This endeavour may require revising the creative class concept to meet the realities of peripheral regions, since it is naïve to expect that they simply replicate processes observed in metropolitan cores. A serious analysis of the creative class in rural and remote areas will also serve to avoid fallacies of blind application of now popular "Floridian" policies, while helping to identify useful practices.

Many smaller cities in Canada's periphery, and specifically in the Canadian North, have been constantly searching for new development opportunities, given (among other things) the continuing decline of their base industries (Bone, 2003), although a few places (such as Yellowknife and Inuvik in the Northwest Territories and Elliot Lake in Ontario) have experienced an upturn in recent years. The need to find alternative sources of economic growth appears to be the inevitable consequence of deteriorating terms of trade for staples in today's world (Sarkar, 1994). The process of economic restructuring in the resource industry caused significant out-migration and depopulation, leaving many northern towns devoid of younger, highly educated and skilled individuals and without the fiscal means to reverse these trends. Other communities, however, have benefited from an influx of younger, more educated, skilled, and creative persons, including highly skilled equipment operators and the local bohemiansartists, singers, and crafters.

Past studies have shown not only that the northern labor force is disadvantaged in terms of skills and education (Bone and Green, 1984; Hull, 2000), but also that a higher quality of human capital in Canadian peripheral areas is associated with better economic performance (Bollman, 1999). Does this mean that in an era when the economic prosperity of regions is likely to depend on their creative human capital, northern communities are doomed to be losers? Or is there a place for talent in the cold? What is the geography of the northern creative class, and what are the regional differences in attracting or losing it?

This study aims to address these questions. My main objectives are to discuss the utility of the creative class argument to the case of northern Canadian communities and to measure and map the creative class in the Canadian 
North. I have redesigned the creative class metrics and used them to rank northern communities. This ranking can help planners to develop alternative strategies of regional growth in the Canadian periphery. I explore interrelationships among different groups within the creative class, between occupation- and education-based measures of the creative class, and between these creative class metrics and indicators of quality of place. Special attention is given to the Native population as a potential element of the northern creative class.

\section{BACKGROUND: HUMAN CAPITAL, CREATIVE CLASS AND THE PERIPHERY}

Geographers started to consider human capital as a crucial factor of regional economic growth and development in the late 1970s (Jacobs, 1984). Since that time, a number of further elaborations have provided empirical evidence of a relationship between economic development and the ability to attract and embrace creative and educated people (Glaeser, 2000; Desrochers, 2001; Florida, 2002a). The link between economic growth and human capital is closely associated with the notion of knowledgedriven growth (Romer, 1990).

Drawing on the notion of human capital, Florida (2002b) suggested that the advancement of regions depends on whether they possess a specific qualitative type of human capital: creative capital. From this perspective, the major driving force of economic development is creative people, or the creative class. The creative class includes not just educated individuals or high-tech workers, but all people who are "engaged in [paid] work whose function is to create meaningful new forms" (Florida, 2005:34, italics in original). Therefore, the notion of the creative class goes beyond traditional representations of a highly skilled labor force, knowledge workers, and so forth. The creative class may be viewed as being based on two conceptual elements: human creativity (which defines creative) and economic or labor status (which defines class).

The growing importance of creative workers in the new economy triggered changes in the way we conceive regional economic development. Porter (1998) noted that successful clusters of such workers produce and maintain a set of competitive advantages in efficiency, effectiveness, and flexibility that enhance productivity and the ability to innovate. Florida offered his own three major components of competitiveness in the new economy: technology, talent, and tolerance (Florida, 2005). He found that all three were closely related to high levels of spatial economic competitiveness. Here, technology is defined in its broadest sense, as a primary output of innovation, and is measured by the high-tech sector concentration in a metropolitan area; talent is a measure of a highly educated labor force; and tolerance is conceptualized in terms of openness, inclusiveness, and diversity. According to Florida (2005), cities that are well endowed with all three T's have an advantage in accumulating creative capital and achieving high levels of economic competitiveness (Florida, 2002a, 2005).

A number of opponents fiercely criticized Florida's thesis. Some pointed out the lack of evidence of causality between the creative class and economic growth in thriving urban areas, where it is unclear whether the creative class fosters growth or the growth attracts the creative labor force (Glaeser, 2005; Shearmur, 2007). Other critics focused on Florida's interpretations of the creative class as privileged urban techno-elite, on his metropolitan culturalism, or on his clichéd policy scripts (Peck, 2005; Markusen, 2006; Scott, 2006). Here I largely leave this discussion aside, partially because of space limitations, but also because it concerns metropolitan regions almost exclusively and thus says little about peripheries. The creative class in non-metropolitan areas may have a somewhat different role than it has in large metropolitan areas. The main arguments of the creative class debate should therefore be reconsidered accordingly once enough evidence has been collected.

Frontier regions have always been viewed as a special case of regional economic development. Core-periphery theorists have documented the marginal, vulnerable, structurally truncated, and functionally dependent character of frontier economies (Friedmann, 1996). Uneven power relations with the southern core, remoteness, and isolation limit the efficiency and flexibility of frontier economies and have determined their current path of development. The inability of marginal regions to take advantage of new economic opportunities provided by the knowledge economy has had different explanations. Under the classic core-periphery concept (Friedmann, 1966), for example, resource frontiers are the last in line to enjoy the "trickledown effect" from the core. Dependency theorists see little chance for exploited peripheries to benefit from new economic opportunities that do not eliminate dependency, but merely change its form (Amin, 2001). Alternatively, institutionalists argue that "learning" (Morgan, 1997) and endogenous growth (Romer, 1990) in the peripheral regions are inhibited by limited local capacities (institutional and infrastructural) and the lack of human capital (Hanson, 2000). The disconnectedness of frontier firms from communities and networks of practice (Gertler, 2005) prevents the transfer of tacit knowledge. In addition, peripheral regions suffer from the "branch plant syndrome," in which linkages with externally located headquarters replace local entrepreneurship and innovativeness. In sum, most peripheries benefit neither from initial conditions, nor from the internal or external processes that can induce a desired transformation.

A path-dependency approach seems to be another useful way to interpret the disadvantage of peripheries. Pathdependency is the persistence of historically and socially embedded organizational trajectories, i.e., specific arrangements of means that are oriented towards increasing productivity and competitiveness (Lundvall, 1992; Bathelt 
and Glucker, 2003). Technological, organizational, and social settings in regional economies have traditionally been oriented to follow the logic of increasing returns (Arthur, 1996) by dwelling on the existing technological paradigm. Typically, however, the accumulation of such returns cannot continue to increase indefinitely, and the absence of change in the chosen trajectory results in "lockin" (Grabher, 1993), whereby a region eventually loses its competitiveness. To ensure future prosperity, the regional innovation system must develop or assume a new technological paradigm through economic, institutional, and social transformation.

The development path for the Canadian North has been set largely by discourses and practices of Harold Innis's staple theory (Innis, 1956). In a staple economy, the physical nature of a resource, not the knowledge used to produce it, provides a desired comparative advantage. Regional innovation systems depend on very narrow flows of knowledge through a few major institutional agents, such as the state and large corporations (Bone, 2003). The monopolistic character of resource extraction means that there are no competing technologies or other forms of innovation that could weaken the rigidity of the current techno-economic trajectory (Clark et al., 2001). Consequently, the condition of path-dependency in frontier communities remains exceptionally strong, preventing them from being successful in a modern economic competition.

In the case of such lock-in, a region has two possibilities: to create a new path or develop new forms of competitiveness (regional reinvention), or to decline (Bathelt and Boggs, 2005). A postulate of the new path-creation concept is that scientific, institutional, economic, and social shifts that allow inventing or adopting new knowledge are among the most important arrangements that can lead to regional selfreinvention (Bassanini and Dosi, 2001). Schienstock (2007) argues that a new window of opportunity is opened up by a combination of a new knowledge paradigm, economic pressures to adapt to the new paradigm, change events that generate and support the transformation process, and courses of action that push techno-economic development in a new direction. Some of these change events-a pressure to foster sustainable development, new technological opportunities, the effects of globalization, regional self-determination, and the devolution of power-are already in place in the Canadian periphery. Why, then, do only a few peripheral regions demonstrate signs of new path creation? Is there a missing factor?

The fallacy of structural models of development, whether neoclassical or institutional, is the neglect of human agency as a key transformative factor. Agents of transformation, which in fact are a critical and necessary component of change, can be political institutions, firms, or non-governmental organizations. However, in the end, the agents of change are people: it is individuals and groups of individuals who write the innovation history of the region (Bassanini and Dosi, 2001). As Schienstock (2007:95) points out, "to explain the development of a new...trajectory, we cannot only refer to objective factors such as new opportunities, economic pressures, or change events.... Path creation [should be] seen as a process of mindful deviation by people who have an understanding of the opportunities that the new paradigm offers... Therefore, the transformation process to a great extent depends on the engagement of social pioneers such as scientists, politicians and entrepreneurs prepared to initiate and conduct anticipatory institutional change." In other words, a regional innovation system can move on from path-dependency and reinvent itself if it possesses the necessary creative capital.

So far, there is only limited evidence of the transformative role that the creative class plays in the periphery. The importance of creative individuals in innovative processes in remote regions has been highlighted in a number of studies from different regions (Hayter et al., 1994; Aarsæther, 2004; Ferrucci and Porcheddu, 2006). Some researchers have observed that less favorable business and social environments of the periphery amplify the importance of creativity and require individual innovators and firms to be more creative than in the core (North and Smallbone, 2000; Aarsæther, 2004). More recently, a formal analysis by McGranahan and Wojan (2007) indicated that major conceptual links between the creative class and economic development exist in American nonmetropolitan settings.

It is difficult to argue that the creative capital in peripheral northern communities can make them successful in competing with national and global innovation powerhouses, but it is plausible to suggest that the availability of this factor improves their prospects for future economic transformation and development. This theory, however, remains the subject of ongoing research. A necessary first step is to study the nature and spatial distribution of creativity in the Canadian North.

\section{APPROACH AND METHODS}

Much of the creative class literature is devoted to developing two sets of measures: one to quantify the creative class, and the other to measure the "pull-factors" responsible for attracting creative people to "high-quality" places. Conventionally used indices include the talent index, the tech pole index, the melting pot (or mosaic) index, and the bohemian index (Table 1). However, as critics have pointed out, the traditional creative class metrics, by concentrating on formal education credentials and technological occupations, fail to capture the diversity of the creative class. I consider the creative class as a heterogeneous entity consisting of at least four large groups-scientists, entrepreneurs, leaders, and bohemians-that apply creativity in different ways. This more inclusive four-sector model of the creative class is adopted in this study. Accordingly, the creative class metrics must be extended. All measures also have to be redefined to reflect the Canadian context. 
TABLE 1. Indices of creative class metrics, measures of quality of place, and measure of technology sector specialization used in the study to analyze the creative capital of communities in northern Canada. Traditional measures are based on Gertler et al. (2002), and new measures were developed by the author for this study. National Occupation Classification (NOC) groups are used to define types of occupations (Human Resources and Social Development Canada, 2008).

\begin{tabular}{|c|c|c|}
\hline Index & Description & Target of Measurement \\
\hline
\end{tabular}

\section{Creative Class Metrics: Traditional}

Talent Index (TI)

Bohemian Index (BI)

Creative Class Metrics: New

Leadership Index (LI)

Entrepreneurship Index (EI)

Applied Science Index (ASI)

Quality of Human Resources Index (QHRI)

Creative Drive Index (CDI)

Measures of ‘Quality of Place’: Traditional

Mosaic Index (MI)

Visible Minority Ratio (VMR)

Measures of 'Quality of Place': New

Common-Law Couples Ratio (CLCR)

Feminist Index (FI)

Aboriginality Index (AI)

Resource-dependency Index (RDI)

Measure of Technology Sector Specialization

Tech Pole Index (TPI)

Location quotient of the employment in North American Industry Classification System (NAICS) high technology sectors (information and cultural industries and

professional, scientific and technical services).
Location quotient of the population over 20 years of age who have a university degree.

Location quotient of the employment in artistic and creative occupations: "Art and Culture" (NOC group F).

Location quotient of people with leadership and managerial occupations (NOC group A).

Location quotient of people with business occupations (NOC group B).

Location quotient of people with applied science occupations (NOC group C).

Integral indicator that combines the educational and professional characteristics of the population and is defined as half the sum of the percentage of people with a university degree and a creative occupation.

Calculated by multiplying the TI by LI (i.e., by combining talent and leadership).

Proportion of the total population that is foreign-born.

Proportion of visible minorities in total population.

Proportion of population in common-law relationship.

Location quotient of women in managerial (leadership) occupations.

Proportion of people with aboriginal identity (by the Census definition) in total population.

Location quotient of employment in the occupations unique for the primary sector.
Level of formal education of the labour force

Creative class: bohemians

Creative class: leaders

Creative class: entrepreneurs

Creative class: scientists

Degree to which the region's labor force has university education and is engaged in creative professional activity

"Power" of the creative drive in a region

Society's diversity

Society's diversity

Society's tolerance

Society's openness, "low barriers of entry"

Presence of aboriginal population

A degree of resource reliance

Specialization in technology sectors
A chosen set of indicators (Table 1) consists of two groups: measures of the creative class and measures of quality of place (or of a place's attractiveness to the creative class). In addition, the Tech Pole Index (TPI) is used to measure a community's specialization in the technology sector. I define traditional indicators in both groups in the manner laid out by Gertler et al. (2002), except that I calculate the creative class indices as location quotients, not as simple shares. A location quotient (LQ) is a measure of the relative status of a phenomenon (e.g., employment in the technology sector) in a given region compared to a reference region (Canada). This is a more advantageous measure, because it compares all communities with a single common denominator, in this case with the national benchmark. The formula for calculating LQ is:

$$
L Q_{i}=\frac{\lambda_{n}}{\lambda_{c}}
$$

in which $L Q_{i}$ is a location quotient of phenomenon $i$ (industry, occupation, education, etc.), $\lambda_{n}$ is the share of the population with a measured characteristic $i$ in region $n$ (North) and $\lambda_{c}$ is the share of the population with the same 
characteristic in Canada. If $L Q$ is greater than 1 , a given phenomenon is more significant (applies to a larger share of the population) in the study region than in the country as a whole.

Following the four-sector model, the creative class occupational metrics include four group-specific indices: the bohemian index (BI), the leadership index (LI), the entrepreneurship index (EI), and the applied science index (ASI), each measuring a distinct creative class group (see definitions in Table 1). The talent index (TI), as in Florida (2002a), measures the level of formal education of the labor force. I also developed two composite indices: the quality of human resources index (QHRI) and the creative drive index (CDI). All together, I call all these indices the creative class metrics. The QHRI is an indicator that integrates the educational and professional characteristics of the population. It is defined as half the sum of the percentage of people with a university degree $\lambda^{i}{ }_{u n i}$ and the percentage of people with creative occupations $\lambda_{\text {cr.occup }}^{i}$ :

$$
\left.Q H R I_{i}=0.5 \sum \lambda_{\text {uni }}^{l} ; \lambda_{\text {cr.occup }}^{l}\right)
$$

The QHRI attempts to provide a proxy for an actual share of people who not only have higher education, but also are engaged in creative professional activity. This index, perhaps, may serve as the best indicator of the creative class size. The CDI is a measure of the "power" of the creative drive in a region. The CDI is calculated by multiplying the TI by the LI (i.e., by combining the talent and leadership indices). It is designed to portray the ability of the creative class to lead and, thus, to deliver a regional breakthrough.

The measures of quality of place (Table 1) incorporate the mosaic index (MI), the visible minority ratio (VMR), the common-law couples ratio (CLCR), the feminist index $(\mathrm{FI})$, the aboriginality index (AI), and the resource dependency index (RDI). The first two indices aim to measure population diversity. The CLCR and FI target the openness and tolerance of a place (similarly to the gay index; Florida, 2002a). Florida singled out tolerance, openness, and diversity as the leading factors attracting the creative class (Florida and Gates, 2001; Florida, 2002a, b; Gertler et al., 2002). The AI is designed to reflect the role of aboriginal population and heritage in accumulating the creative class. The RDI measures community resourcereliance. The AI and RDI are designed to account for special social and economic characteristics of the North.

As noted above, I also use the tech pole index (TPI) as a proxy for a community's specialization in high-technology sectors (Table 1). The TPI was first developed by the Milken Institute and later used by Florida (2002a) as an indicator of a region's high-technology specialization. The TPI is calculated here as a location quotient of employment in high-technology sectors of the North American Industry Classification System (NAICS, 2007; Table 1).
To analyze the data, I first computed the indices that characterize the creative class for northern communities and compared them to those for the two control regions: Canada and the City of Toronto. Toronto was selected as the key comparator city to represent the country's creative core (Gertler et al., 2002). I then studied indicators of attractiveness in a similar manner. Correlation and principal-components analyses were used to discover the relationships among indices, both within each group and between the two groups. In this step, I also assessed the performance and relevance of the selected measures. I then ran two regression models - log-transformed ordinary least squares (OLS) with a stepwise elimination of insignificant variables-to test possible dependencies between the creative class, attractiveness factors, and specialization in high-technology sectors. After exploring individual metrics, I ranked the northern communities using both the creative class measures and the attractiveness measures. Overall, two composite rankings were produced: one by combining equally weighted individual rankings of the creative class indices (TI, LI, EI, BI, and ASI), and the other by combining rankings of the quality of place indicators (MI, VMR, FI, CLCR, AI, and RDI). I identified leading communities ("creative hot spots") and those lagging behind. Finally, I conducted a cluster analysis ( $k$-means method) to detect the extent of typological heterogeneity within the data set. An exclusively quantitative approach to studying the creative class has received criticism for its excessive emphasis on statistical associations at the expense of qualitative assessment (Markusen, 2006); however, it suits my goal here, which is to conduct an exploratory empirical study aimed at quantifying and measuring the creative class in the Canadian North.

My working definition of the North includes the three territories and the northern portions of seven provinces. Following Bone (2003), I selected 34 "most important" northern cities and towns (Fig. 1). ("Nordicity" is a complex concept that is not strictly limited by a geographic location. Whereas there is no agreement on these matters, most geographers would argue that limiting the North to administrative boundaries of the Territories, i.e., "north of 60 ," is not necessarily a correct way of defining it. Bone's definition that I accept in this paper comes from the original study of Louis-Edmond Hamelin [1975], which demonstrated that conditions of nordicity continued far into the south. For example, Hamelin traced the border of the Near North just outside of North Bay and Winnipeg. The recent Statistics Canada delineation of the North [McNiven and Puderer, 2000] uses generally similar boundaries.) The largest urban centre is ChicoutimiJonquière (census metropolitan area), Quebec with a population of approximately 155000 in 2001, and the smallest is Rankin Inlet, Nunavut with 2177 residents (Fig. 1, Table 1). All data were obtained from Statistics Canada's 2001 Census database (Statistics Canada, 2002). 


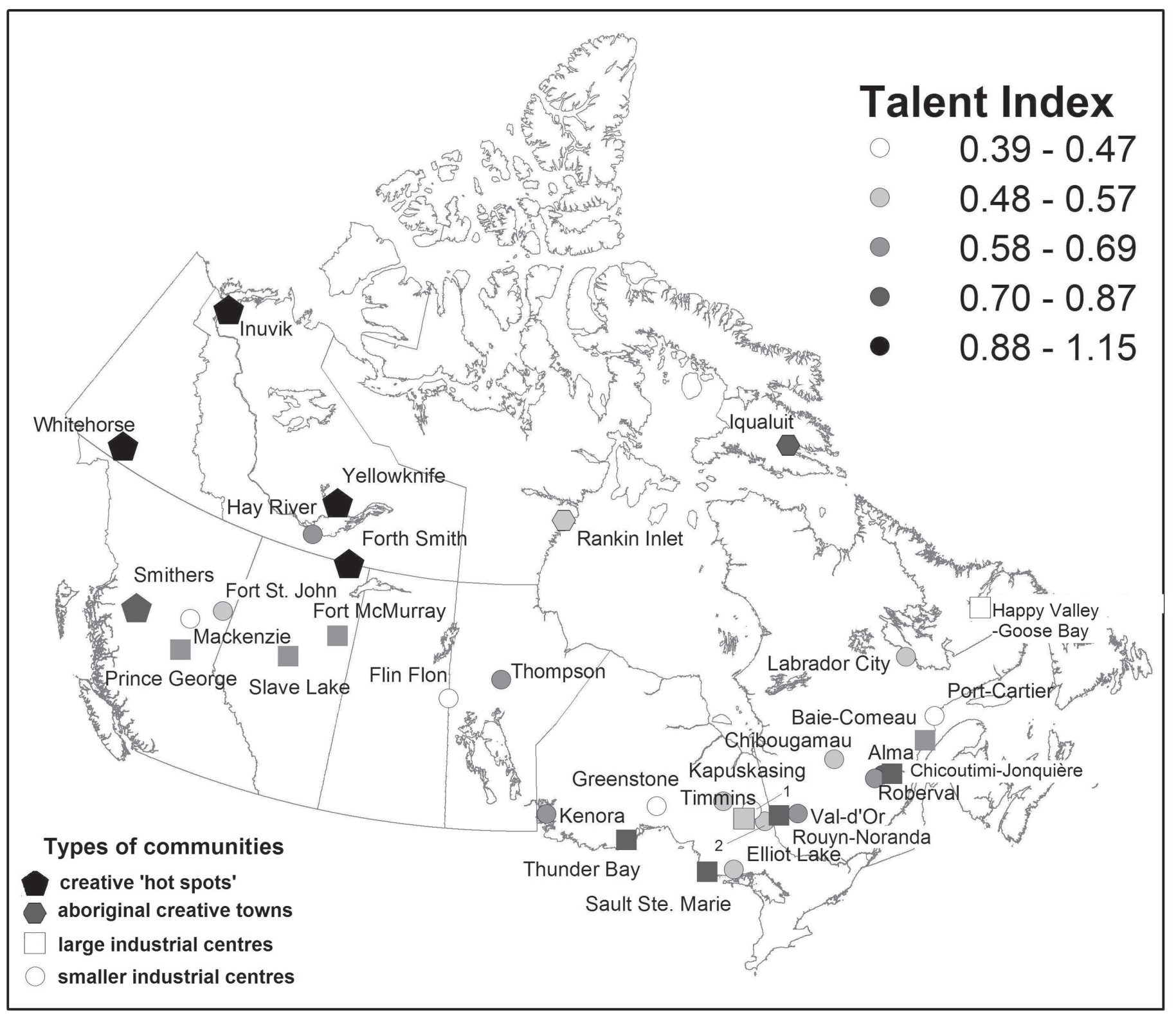

FIG. 1. Thirty-four northern communities (grey tones represent the Talent index). $1=$ Iroquois Falls and $2=$ Kirkland Lake.

\section{RESULTS AND DISCUSSION}

\section{Creative Class Characteristics}

The calculation of the talent index (TI) for 34 northern cities and towns (Table 2) reveals an apparent shortage of highly educated individuals: on average, the TI in the entire data set is only 0.65 (in Toronto it is 1.42). However, there is a leading pair of communities - the territorial capitals, Whitehorse and Yellowknife-where the TI exceeds 1.0 (Table 2; Fig. 1). Fort Smith takes third place, with a TI matching the Canadian average. The second tier of cities $(0.8 \leq \mathrm{TI} \leq 1.0)$ consists of Iqaluit, RouynNoranda, Thunder Bay, and Inuvik. Interestingly enough, Gertler et al. (2002) ranked Thunder Bay 20th among the 25 largest metropolitan regions. In sum, despite the fact that the northern labor force is generally short of educational credentials, there are still places with a prominent concentration of talent.

The leadership index (LI) has a different distribution pattern (Table 2). The average LI is 0.9. In addition to the three territorial capitals, five other communities, including Inuvik, Hay River, Rankin Inlet, Smithers, and Fort Smith, have a higher-than-average proportion of managerial occupations. Clearly, the leadership potential of the territorial North is quite high. In old industrial and resource towns, on the other hand, the leadership component of the creative class is underdeveloped (Table 1), reflecting their dependency on externally located decision making (the branch plant syndrome).

The entrepreneurship index (EI) exhibits a somewhat similar distribution (Table 2). Rankin Inlet is ranked first 
TABLE 2. Characteristics of the creative class in northern communities. Communities are ranked from strongest to weakest in creative class, using a composite ranking of five indices (TI, BI, LI, EI, and ASI). Comparative figures for Toronto and Canada as a whole are also given. For details of indices, see Table 1 .

\begin{tabular}{|c|c|c|c|c|c|c|c|c|c|c|}
\hline Community name & Population 2001 & $\mathrm{TI}$ & LI & EI & ASI & BI & QHRI & CDI & TPI & Rank \\
\hline Yellowknife & 16,541 & 1.14 & 1.70 & 1.12 & 1.43 & 1.12 & 41.0 & 361.70 & 1.14 & 1 \\
\hline Whitehorse & 19,058 & 1.15 & 1.56 & 1.13 & 1.04 & 1.30 & 40.7 & 338.90 & 1.09 & 2 \\
\hline Iqaluit & 5,236 & 0.87 & 1.68 & 1.12 & 0.93 & 1.94 & 39.1 & 304.15 & 0.77 & 3 \\
\hline Fort Smith & 2,185 & 0.99 & 1.23 & 0.94 & 1.15 & 1.03 & 38.4 & 256.07 & 0.60 & 4 \\
\hline Inuvik & 2,894 & 0.80 & 1.66 & 1.00 & 1.01 & 0.77 & 35.6 & 275.68 & 0.75 & 5 \\
\hline Smithers & 5,414 & 0.77 & 1.21 & 1.00 & 1.45 & 0.72 & 32.3 & 199.99 & 1.09 & 6 \\
\hline Rouyn-Noranda & 28,269 & 0.86 & 0.83 & 0.97 & 1.05 & 0.74 & 32.5 & 173.98 & 0.62 & 7 \\
\hline Rankin Inlet & 2,177 & 0.57 & 1.23 & 1.19 & 0.71 & 1.44 & 34.1 & 181.80 & 0.62 & 8 \\
\hline Chicoutimi-Jonquière & 154,938 & 0.78 & 0.62 & 0.89 & 1.06 & 0.62 & 29.0 & 122.75 & 0.77 & 9 \\
\hline Slave Lake & 6,600 & 0.62 & 1.01 & 0.83 & 0.88 & 0.74 & 27.0 & 132.83 & 0.57 & 10 \\
\hline Thunder Bay & 121,986 & 0.84 & 0.79 & 0.87 & 0.76 & 0.79 & 29.2 & 154.49 & 0.69 & 11 \\
\hline Val-d'Or & 22,748 & 0.64 & 0.77 & 0.90 & 0.85 & 0.69 & 27.0 & 117.09 & 0.86 & 12 \\
\hline Hay River & 3,510 & 0.63 & 1.27 & 1.05 & 0.78 & 0.36 & 29.6 & 164.95 & 0.42 & 13 \\
\hline Prince George & 85,035 & 0.62 & 0.85 & 0.94 & 0.87 & 0.56 & 26.6 & 111.48 & 0.83 & 14 \\
\hline Baie-Comeau & 23,079 & 0.66 & 0.60 & 0.81 & 1.14 & 0.60 & 26.9 & 91.28 & 0.36 & 15 \\
\hline Sault Ste. Marie & 78,908 & 0.75 & 0.69 & 0.84 & 0.85 & 0.59 & 27.5 & 129.57 & 0.59 & 16 \\
\hline Thompson & 13,256 & 0.69 & 0.65 & 0.79 & 1.02 & 0.46 & 27.5 & 94.09 & 0.36 & 17 \\
\hline Fort McMurray & 41,466 & 0.65 & 0.93 & 0.78 & 1.25 & 0.32 & 25.1 & 113.70 & 0.50 & 18 \\
\hline Alma & 30,126 & 0.73 & 0.56 & 0.90 & 0.69 & 0.68 & 26.7 & 98.50 & 0.64 & 19 \\
\hline Kirkland Lake & 8,616 & 0.49 & 0.85 & 0.98 & 0.70 & 0.48 & 27.8 & 113.08 & 0.60 & 20 \\
\hline Happy Valley-Goose Bay & 7,969 & 0.47 & 0.96 & 0.97 & 0.94 & 0.29 & 26.6 & 96.08 & 0.47 & 21 \\
\hline Elliot Lake & 11,956 & 0.54 & 0.63 & 0.76 & 0.45 & 1.26 & 27.0 & 128.69 & 0.88 & 22 \\
\hline Kenora & 15,838 & 0.66 & 0.91 & 0.74 & 0.68 & 0.41 & 26.2 & 135.96 & 0.36 & 23 \\
\hline Timmins & 43,686 & 0.52 & 0.68 & 0.82 & 0.93 & 0.40 & 24.3 & 86.12 & 0.66 & 24 \\
\hline Fort St. John & 16,034 & 0.48 & 0.98 & 0.76 & 0.79 & 0.44 & 23.1 & 92.82 & 0.58 & 25 \\
\hline Kapuskasing & 9,238 & 0.49 & 0.76 & 0.76 & 0.57 & 0.57 & 22.7 & 91.86 & 0.43 & 26 \\
\hline Labrador City & 7,744 & 0.49 & 1.04 & 0.56 & 0.65 & 0.37 & 20.0 & 106.63 & 0.19 & 27 \\
\hline Mackenzie & 5,206 & 0.46 & 0.55 & 0.79 & 0.88 & 0.24 & 20.0 & 51.52 & 0.31 & 28 \\
\hline Roberval & 10,906 & 0.59 & 0.49 & 0.69 & 0.54 & 0.48 & 22.7 & 71.37 & 0.31 & 29 \\
\hline Chibougamau & 7,922 & 0.50 & 0.58 & 0.75 & 0.66 & 0.52 & 21.9 & 65.21 & 0.38 & 30 \\
\hline Flin Flon & 6,000 & 0.46 & 0.68 & 0.78 & 0.62 & 0.34 & 21.2 & 69.49 & 0.30 & 31 \\
\hline Iroquois Falls & 5,217 & 0.46 & 0.51 & 0.65 & 0.40 & 0.76 & 20.6 & 60.68 & 0.14 & 32 \\
\hline Port Cartier & 6,412 & 0.39 & 0.53 & 0.76 & 0.79 & 0.29 & 20.4 & 51.01 & 0.27 & 33 \\
\hline Greenstone & 5,662 & 0.43 & 0.67 & 0.54 & 0.57 & 0.41 & 20.5 & 62.99 & 0.29 & 34 \\
\hline Canada & $30,007,094$ & 1.00 & 1.00 & 1.00 & 1.00 & 1.00 & 33.4 & 224.66 & 1.00 & - \\
\hline Toronto & $4,682,897$ & 1.42 & 1.30 & 1.22 & 1.28 & 1.32 & 42.4 & 400.14 & 1.75 & - \\
\hline
\end{tabular}

(almost tied with Toronto!), pointing to the large creative capacity of Native-run businesses that are favorably located in an emerging regional centre and receive adequate government support. The three territorial capitals closely follow Rankin Inlet, building on the advantage of being political and economic headquarters. Only a few other communities (Hay River, Inuvik, Smithers, Kirkland Lake, Happy Valley-Goose Bay, Rouyn-Noranda, Fort Smith, and Prince George) have a relatively developed entrepreneurial class. Overall, the North seriously lacks entrepreneurial capital.

The applied science index (ASI) adds some new insights into the pattern of scientists and engineers in the North. In this case, high index scores are associated with active industrial centres: Smithers, Fort McMurray, Yellowknife, Baie-Comeau, Rouyn-Noranda, and Thompson (Table 2). These towns are potential centres of industrial high-tech production. Nonetheless, the North, with an average ASI of 0.85 , is behind the rest of Canada in high-skilled technical occupations.

In previous studies, the bohemian index (BI) has been considered solely as an attractiveness factor, but not as a characteristic of the creative class (Florida, 2002a; Gertler et al., 2002). As discussed above, a broader definition of the creative class requires incorporating bohemians as one of its components. On average, the share of bohemians in northern communities is lower than in Canada, although in two towns (Iqaluit and Rankin Inlet) it is even greater than in Toronto. Accordingly, Table 2 shows a considerable variation within the North. For example, Iqaluit has a BI value almost ten times that of Mackenzie (1.94 compared to 0.24$)$. The five top communities-Iqaluit, Whitehorse, Yellowknife, Rankin Inlet, and Elliot Lake_are distantly followed by Slave Lake, Smithers, and Thunder Bay.

The quality of human resources index (QHRI) is one of the integral indices. This measure is derived from both educational and occupational characteristics of the population. Not surprisingly, the QHRI for Toronto is 1.3 times greater than the Canadian average and clearly illuminates Toronto's high-creativity profile (Table 2). As expected, northern communities do not have high QHRI scores. However, four communities-Yellowknife, Whitehorse, Iqaluit, and Fort Smith-stand out as those with greatest creative potential, with QHRI scores that exceed the Canadian average, and Inuvik, Rankin Inlet, Rouyn-Noranda, and Smithers have QHRI scores around the national 
TABLE 3. Correlation matrix of the creative class metrics and indicators of attractiveness.

\begin{tabular}{|c|c|c|c|c|c|c|c|c|c|c|c|c|c|c|}
\hline Indices $^{1}$ & $\mathrm{CDI}$ & QHRI & TPI & TI & BI & LI & EI & ASI & MI & VMR & CLCR & FI & AI & RDI \\
\hline CDI & 1.000 & $.950 * *$ & $.712 * *$ & $.872 * *$ & $.835^{* *}$ & $.876^{* *}$ & $.744 * *$ & $.559 * *$ & $.370 *$ & $.411^{*}$ & .227 & $.692 * *$ & $.523 * *$ & $-.504 * *$ \\
\hline QHRI & & 1.000 & $.735^{* *}$ & $.890 * *$ & $.819 * *$ & $.817 * *$ & $.849 * *$ & $.613 * *$ & .302 & .328 & .293 & $.622 * *$ & $.568 *$ & -.575 \\
\hline TPI & & & 1.000 & $.692 * *$ & $.596 * *$ & $.597 * *$ & $.679 * *$ & $.545 * *$ & $.531 * *$ & $.379 *$ & .069 & $.429 *$ & .145 & $-.398 *$ \\
\hline TI & & & & 1.000 & $.701 * *$ & $.563 * *$ & $.633 * *$ & $.636^{* * *}$ & $.356^{*}$ & $.369^{*}$ & .180 & $.360^{*}$ & .256 & $-.521^{*}$ \\
\hline BI & & & & & 1.000 & $.743 * *$ & $.644 * *$ & .297 & .202 & .209 & .338 & $.597 * *$ & $.527 * *$ & $-.472 *$ \\
\hline LI & & & & & & 1.000 & $.723 * *$ & $.354 *$ & .292 & .276 & .178 & $.886^{* * *}$ & $.697 * *$ & $-.432 *$ \\
\hline EI & & & & & & & 1.000 & $.537 * *$ & .204 & $.340^{*}$ & .315 & $.485^{* *}$ & $.551 * *$ & $-.587 * *$ \\
\hline ASI & & & & & & & & 1.000 & .294 & $.486^{*}$ & .214 & .126 & .195 & -.305 \\
\hline MI & & & & & & & & & 1.000 & $.694 * *$ & $-.540 * *$ & .305 & .035 & -.132 \\
\hline VMR & & & & & & & & & & 1.000 & -.189 & .192 & .157 & -.150 \\
\hline CLCR & & & & & & & & & & & 1.000 & .042 & .276 & -.179 \\
\hline FI & & & & & & & & & & & & 1.000 & $.667 * *$ & -.213 \\
\hline AI & & & & & & & & & & & & & 1.000 & -.227 \\
\hline RDI & & & & & & & & & & & & & & 1.000 \\
\hline
\end{tabular}

\footnotetext{
${ }^{1}$ For details of indices, see Table 1.

** Correlation is significant at the 0.01 level (2-tailed), * Correlation is significant at the 0.05 level (2-tailed).
}

average (Table 2). This pattern, again, illustrates a strong unevenness in the distribution of high-quality human capital among northern Canadian communities.

The creative drive index (CDI), which combines education and leadership characteristics of northern communities, illustrates the "propulsive capacity" of the creative class. Generally, the pattern of the CDI across the North mirrors that of the QHRI. However, a much stronger standing of Toronto against the Canadian average suggests the independence of this parameter. Among northern communities, the discrepancy between the capitals and the rest of the North is substantial. Yellowknife, Whitehorse, and Iqaluit are the only communities to demonstrate high CDI values. This is a sign that the three capitals possess the most developed creative class and the greatest potential for increased creativity. Thus, the CDI results show that these towns are most likely to be the creative class hot spots.

The tech pole index (TPI) demonstrates that only a few northern communities have a considerable concentration of high-tech employment and specialize in technologyintensive industries (Table 2). Only Yellowknife, Whitehorse, and Smithers have slightly higher shares of such employment than Canada on average. In old industrial towns, the technology sector is particularly small. Fort McMurray, the only growing industrial centre on the list, also has a limited knowledge-based industry.

Correlation and concordance coefficients were used to ensure the consistency (reliability and validity) of the new indices and to analyze the relationships among them statistically. Correlation coefficients illustrate close associations (Table 3 ) between different creative class indices, a likely sign that these measures are reliable (I address the issue of redundancy later). Reliability is confirmed by the high degree of concordance among the new indices (Kendall's coefficient of concordance 0.66). In addition, the strong correlation of the new measures with the established ones (TI, TPI, and BI) indicates the validity of the new indices.
TABLE 4. Principal components of creative class metrics.

\begin{tabular}{lcc}
\hline \hline & \multicolumn{2}{c}{ Components $^{1}$} \\
\cline { 2 - 3 } & 1 & 2 \\
\hline $\mathrm{BI}^{2}$ & .924 & \\
LI & .858 & .269 \\
CDI & .802 & .535 \\
QHRI & .779 & .598 \\
EI & .664 & .536 \\
TPI & .578 & .592 \\
TI & .570 & .692 \\
ASI & & .959 \\
Percent of variance & 49.3 & 34.4 \\
\hline \hline
\end{tabular}

${ }^{1}$ Extraction method: PCA, Jolliffe criterion; rotation method: varimax with Kaiser normalization. Loadings less than 0.1 are not reported.

${ }^{2}$ For details of indices, see Table 1.

Correlation results (Table 3) strongly support the idea that different groups of the creative class are clustered and interdependent. Four creative class groups, most likely, attract each other, and creative class clusters benefit from this synergy. That is why, for example, previous studies found the concentration of bohemians useful to explain the attractiveness of cities to the talented (Florida, 2002a, b). Table 3 also illustrates that the specialization in hightechnology industries (TPI) in the North is associated with a well-educated and strong creative class, much as it is in urban areas. The notable difference, however, is that hightech activities are related not only to highly educated and applied science workers, but, even more strongly, to the concentration of entrepreneurs and managers. It appears that in peripheral settings, the availability of leadership and entrepreneurial capabilities is a key factor in developing knowledge-based industries.

In order to explore the covariance among variables, all creative class indices were subjected to a principal components analysis (Table 4). Its results demonstrate several important patterns. First, the creative class indicators in northern communities constitute two distinct groups: 
TABLE 5. Indicators of attractiveness to the creative class in 34 northern Canadian communities, compared to Toronto and Canada as a whole. Communities are ranked from most to least attractive, using a composite ranking of six indices (MI, VMR, CLCR, FI, AI, and RDI). For details of indices, see Table 1.

\begin{tabular}{|c|c|c|c|c|c|c|c|}
\hline Community Name & MI & VMR & CLCR & FI & AI & RDI & Rank \\
\hline Whitehorse & 10.8 & 4.8 & 13.9 & 1.34 & 15.8 & 0.3 & 1 \\
\hline Inuvik & 5.9 & 2.8 & 21.0 & 1.75 & 58.2 & 0.5 & 2 \\
\hline Yellowknife & 10.4 & 7.5 & 16.0 & 1.48 & 22.0 & 0.7 & 3 \\
\hline Rankin Inlet & 2.8 & 1.8 & 18.5 & 1.83 & 79.0 & 0.2 & 4 \\
\hline Iqaluit & 4.2 & 1.9 & 25.9 & 1.49 & 58.5 & 0.1 & 5 \\
\hline Smithers & 11.8 & 3.5 & 9.0 & 1.00 & 9.9 & 0.8 & 6 \\
\hline Hay River & 4.8 & 3.4 & 15.9 & 1.22 & 44.6 & 0.9 & 7 \\
\hline Elliot Lake & 13.0 & 2.0 & 8.0 & 1.52 & 5.2 & 1.0 & 9 \\
\hline Fort Smith & 5.5 & 2.5 & 15.4 & 1.16 & 59.3 & 1.0 & 9 \\
\hline Fort McMurray & 8.5 & 5.2 & 13.4 & 0.85 & 12.4 & 0.8 & 10 \\
\hline Thunder Bay & 10.9 & 2.2 & 7.3 & 0.83 & 6.7 & 0.6 & 11 \\
\hline Kenora & 5.9 & 1.7 & 8.7 & 1.09 & 10.7 & 0.6 & 12 \\
\hline Sault Ste. Marie & 11.2 & 1.2 & 6.4 & 0.74 & 7.1 & 0.4 & 13 \\
\hline Prince George & 9.8 & 5.3 & 9.5 & 0.81 & 9.4 & 1.1 & 14 \\
\hline Thompson & 6.5 & 3.1 & 13.3 & 0.82 & 34.0 & 2.0 & 15 \\
\hline Fort St. John & 5.6 & 2.8 & 12.6 & 0.81 & 29.8 & 1.9 & 16 \\
\hline Kirkland Lake & 5.7 & 1.2 & 10.2 & 1.17 & 4.9 & 1.3 & 17 \\
\hline Mackenzie & 10.4 & 8.5 & 10.7 & 0.41 & 4.0 & 1.1 & 18 \\
\hline Happy Valley-Goose Bay & 2.2 & 0.5 & 13.1 & 0.77 & 34.3 & 0.6 & 19 \\
\hline Slave Lake & 4.6 & 0.4 & 13.4 & 1.01 & 26.8 & 1.5 & 20 \\
\hline Flin Flon & 4.6 & 1.2 & 9.3 & 0.94 & 12.0 & 2.4 & 21 \\
\hline Timmins & 4.8 & 1.1 & 10.4 & 0.93 & 6.6 & 1.8 & 22 \\
\hline Kapuskasing & 3.6 & 0.9 & 10.1 & 0.74 & 2.9 & 0.6 & 23 \\
\hline Greenstone & 4.7 & 0.3 & 15.5 & 1.07 & 15.1 & 2.4 & 24 \\
\hline Labrador City & 1.7 & 1.1 & 8.9 & 1.26 & 2.3 & 1.9 & 25 \\
\hline Baie-Comeau & 1.1 & 0.6 & 20.9 & 0.64 & 0.6 & 0.3 & 26 \\
\hline Chicoutimi-Jonquière & 0.9 & . & 16.7 & 0.73 & 0.7 & 0.5 & 27 \\
\hline Rouyn-Noranda & 1.4 & 0.5 & 21.6 & 0.82 & 1.2 & 0.9 & 28 \\
\hline Roberval & 0.5 & 0.5 & 16.7 & 0.42 & 5.0 & 0.6 & 29 \\
\hline Val-d'Or & 1.5 & 0.6 & 23.3 & 0.66 & 2.1 & 1.5 & 30 \\
\hline Iroquois Falls & 1.2 & 0.2 & 7.0 & 0.65 & 3.0 & 1.4 & 31 \\
\hline Alma & 0.8 & 0.3 & 16.9 & 0.60 & 0.8 & 0.7 & 32 \\
\hline Chibougamau & 1.1 & 0.6 & 24.7 & 0.50 & 1.8 & 1.8 & 33 \\
\hline Port Cartier & 0.5 & 0.2 & 22.9 & 0.62 & 2.3 & 1.1 & 34 \\
\hline Canada & 18.2 & 13.3 & 9.4 & 1.00 & 3.3 & 1.0 & - \\
\hline Toronto & 43.4 & 36.6 & 5.0 & 1.45 & 0.4 & 0.2 & - \\
\hline
\end{tabular}

technical workers (engineering, applied and natural science occupations) and non-technical creative occupations (including leaders, entrepreneurs, scientists, and bohemians). Importantly, both the TI and the tech pole index exhibit substantial covariance with each group of occupational indicators, implying that both groups are well educated and linked to technological production. Overall, the analysis shows that the CDI and QHRI are the most integrative among the new indices, although principal components did not provide enough evidence to identify any of the introduced indices as redundant.

\section{Factors of Attractiveness}

According to Florida (2002b, 2005), measures of attractiveness may be viewed as pull-factors for the creative class. He alluded to tolerance and diversity as the most important factors of a place's attractiveness to the creative class (and major determinants of quality of place). Thus, higher indices of attractiveness (except for the resourcedependency index) would indicate a competitive advantage in terms of drawing and retaining the creative class.
The bohemian index is considered in the literature among the top measures of attractiveness, so it should be analyzed from this standpoint as well. This index strongly correlates with the talent index and the CDI (Table 3), confirming that it could be a powerful pull-factor. However, my results reveal a weaker interdependence between the BI and TI in the North than was reported by Gertler et al. (2002) for 25 major Canadian cities, which suggests that the northern bohemians are a less powerful pull-factor for talent. For example, two centres of Native arts-Iqaluit and Rankin Inlet-are comparatively modest in terms of residents' education. At the same time, if the integral creative drive index is used, rather than the education-only TI, the strength of the relationship observed in respect to the entire sample improves substantially (Table 4).

A recommended measure of diversity is the melting pot or mosaic index (Florida, 2002a; Gertler et al., 2002). In the Canadian context, however, it has been found a less valid predictor of talent than expected (Gertler et al., 2002). As seen from Table 5, the diversity of northern communities is low compared to that of the rest of Canada. The statistical association between the share of foreign- 
born population and the talent index is positive, but rather moderate (Table 3). The relationship is insignificant for the QHRI. The foreign-born factor in the North seems to be much less important in attracting creativity than in the rest of Canada. Diverse Mackenzie and Elliot Lake have comparatively low educational profiles, and moderately diverse Iqaluit, Inuvik, and Fort Smith rank high in terms of residents' education. At the same time, the overall pattern suggests that diversity is still a considerable pull-factor, as expected. Clusters of creativity in diverse Yellowknife and Whitehorse illustrate this point well.

The visible minority ratio (Tables 3 and 5) was used as an alternative indicator of diversity. Although in most communities the percentage of visible minorities is small, the relationships between the VMR and the talent and the creative drive indices are moderate (as in all smaller cities, see Ottaviano and Peri, 2006), significant, and stronger than those with the mosaic index (Table 3 ). This shows that the visible minority share might be a better indicator of diversity and especially of tolerance, and that the creative class clusters in diverse and tolerant places-even those in the North.

The common-law couples ratio initially failed to explain the distribution of the creative class (Table 3), producing insignificant correlations. However, when the data set was readjusted to eliminate cities and towns in Quebec, which are the obvious positive outliers (see Kerr et al., 2006 for the sociological analysis of this phenomenon), the relationships with the QHRI $(r=0.60)$ and the CDI $(r=0.59)$ became significant. Therefore, the commonlaw-based measure of tolerance is more successful when the Quebec-English cultural heterogeneity is removed.

The feminist (women in leadership) index was designed as an indicator of low entry barriers and openness. Northern economy and leadership have always been perceived as male-driven because males predominate in the region. The analysis reveals that this gendering is not necessarily the case, and that there are profound variations in the role of women across the region. Surprisingly enough, although partially because of the population structure, women tend to hold more leadership positions in many Native communities than in non-Native towns (see Table 5). The empirical evidence (Table 3) confirms that the creative class metrics demonstrate strong and significant positive correlations with the FI. Therefore, the feminist index may be considered as a useful indicator of quality of place and perhaps can be used to substitute the infamous gay index, for which good data are not available. Still, the FI underpredicts the creative class in the capitals and some regional centres, where the creative class apparently is male dominated.

The aboriginality index (AI) results demonstrate that the 34 selected communities have a strong aboriginal presence, and in four of them (Inuvik, Rankin Inlet, Iqaluit, and Fort Smith) aboriginal people predominate (Table 5). However, the AI is difficult to place on either side of the attractiveness scale, since the relationship between
TABLE 6. Principal components of attractiveness factors.

\begin{tabular}{lccc}
\hline \hline & \multicolumn{3}{c}{ Components $^{1}$} \\
\cline { 2 - 4 } & 1 & 2 & 3 \\
\hline MI $^{2}$ & .940 & .127 & \\
VMR & .775 & .152 & .261 \\
CLCR & -.693 & .229 & .439 \\
AI & .197 & .908 & .157 \\
FI & .894 & -.919 \\
RDI & 33.6 & -.103 & 18.9 \\
Percent of variance & 33.8 & 28.8 \\
\hline \hline
\end{tabular}

\footnotetext{
${ }^{1}$ Extraction method: PCA, Jolliffe criterion; rotation method: varimax with Kaiser normalization. Loadings less than 0.1 are not reported.

${ }^{2}$ For details of indices, see Table 1.
}

aboriginality and the creative class is not well understood. A large aboriginal share of the population may indicate a community characterized by both higher tolerance and lower openness. On the other hand, aboriginal communities have their own ways of nurturing and raising internal creativity (e.g., Native arts, entrepreneurship). Table 3 provides evidence that a greater share of aboriginal population in northern towns is a positive sign for creativity, although the creative class structure in such cases is shifted towards a creativity that is not driven by education: aboriginal leadership, entrepreneurship, and bohemians are the major bearers of creativity in many northern towns (Tables 2 and 4). This result may be an outstandingly encouraging signal for communities, since it means they may have the ability to generate creative capital without being solely dependent on the in-migration of creative individuals. However, the capacity of such endogenous growth is limited, and without further advancement in education, future success is unlikely. This observation is clearly an important one and needs thorough further study.

The resource-dependency index (RDI) was chosen as an indicator of economic marginality. It is expectedly high in most northern communities (Table 5). Table 3 demonstrates that resource dependency is negatively correlated with creativity. Thus, the socioeconomic marginality of resource-dependent settlements, the limited diversity of primary sector jobs, and the branch plant culture inhibit the development of creative capital and undermine the attractiveness of such communities to the creative class.

Table 3 also reports correlations among the attractiveness measures themselves, and suggests that they are fairly independent of each other. Strong correlations exist only between several variables - a pattern also reflected in Table 6, where principal components are defined. In particular, the mosaic and visible minority indices appear to be most closely associated. This may not be a surprise, considering that both indicate the diversity and tolerance of the society. The feminist and aboriginality indices also exhibit covariance and constitute another principal component (Table 6). This result is particularly interesting and requires further investigation. In sum, the selected 
indices seem to cover different aspects of attractiveness and do not appear to be redundant, except for the MI, which could potentially be eliminated in favor of the VMR.

\section{Regression Modeling: Exploring Possible Dependencies}

The analysis of correlations proves that there are statistical associations between technology production, the creative class, and quality of place in the Canadian North. However, the direction of causality between the creative class, attractiveness factors, and specialization in hightechnology sectors is debatable, and there is still not enough evidence to establish firm explanatory links between them (Florida, 2005; Shearmur, 2007). Nonetheless, building regression models with exploratory purposes to test possible dependencies (under an assumed scenario) is still informative. It is also useful for examining the multicollinearity of the metrics.

The first model looks at the relationships between the creative class and quality of place. The QHRI is the dependent variable, and the attractiveness factors (Table 3 ) are the independent variables. Accepting the scenario under which quality of place attracts the creative class (Florida, 2002b; McGranahan and Wojan, 2007), one would expect the attractiveness indicators to be good predictors of the QHRI. The final regression equation (with all insignificant variables excluded) is as follows $\left(r^{2}=0.61\right)$ :

$$
\begin{aligned}
\lg Q H R I & =1.15+0.207 \lg C L C R+0.172 \lg F I \\
& -0.124 \lg R D I+0.08 \lg V M R
\end{aligned}
$$

The CLCR and the FI appear to be the strongest predictors, with positive slopes, suggesting that openness and tolerance may play a key role in accumulating high-quality human capital in the North. In contrast, resource dependency (expectedly) may work as a negative factor. Again, these observations, albeit interesting, are merely suggestive, because only detailed qualitative research can establish whether they reflect certain causalities. The MI and AI were discarded by the stepwise regression algorithm as not significant. The MI and VMR exhibited collinearity, but after the former was excluded, the final model (1) did not have a multicollinearity problem.

The second model uses the TPI as regressand and TI, BI, LI, EI, and ASI as regressors, i.e., it assumes another "Floridian" scenario, under which specialization in hightech industries (the TPI) is a function of creative class accumulation. Modeling results $\left(r^{2}=0.64\right)$ support this expectation (all insignificant variables are excluded):

$$
\begin{aligned}
\lg T P I=-0.09 & +0.929 \lg E I+0.505 \lg A S I \\
& +0.366 \lg B I
\end{aligned}
$$

Two potentially important observations stem from this model. First, entrepreneurial, applied science, and artistic occupations, not educational attainment (TI), appear to be the best predictors of the TPI (the TI and LI were not significant). Second, the ambiguity of the relationship between high-tech industrial specialization and the creative class (i.e., whether the creative class boosts the technology sector or the strong technology sector attracts the creative class), typical for urban areas, is less evident here. Two of the regressors (the EI and BI) represent creative class groups that may be least affected by the high-tech job market, but which likely contribute to creating a favorable business environment, generating creative jobs, and attracting a high-quality labor force. This result may point to the special role of entrepreneurship (rather than education) in nurturing knowledge-based industries in the periphery. The model was not seriously affected by multicollinearity.

\section{Rankings and Clusters: Summarizing Geographies of the Creative Class}

After individual characteristics and relationships among indices are clarified, it is possible to identify the communities that have the strongest creative class and the greatest ability to attract it. Table 2 contains a composite creative class ranking of the 34 northern communities that is based on the TI, LI, EI, BI, and ASI indices. The group of six leading communities at the top of the ranking represents the creative core of the North. These towns are Yellowknife, Whitehorse, Iqaluit, Fort Smith, Inuvik, and Smithers. Noticeably, territorial capitals and most regional centres are ranked high, whereas more southerly cities (e.g., Timmins, Thompson, and several Quebec cities) are ranked quite low. This finding suggests that remoteness may be a positive condition for the creative class, probably because a remote location stimulates local leadership, entrepreneurship, and the rise of a northern creative class that includes aboriginal people. Other factors may include a high demand for leadership and other types of creativity in the frontier, the superior political status of northern capitals, unique experience and economic opportunities for young professionals, and a more favorable demographic composition.

The second tier of towns includes Rankin Inlet, RouynNoranda, Prince George, Hay River, Thunder Bay, Chicoutimi-Jonquière, Fort McMurray, and six other communities, predominantly in the provinces. These places have limited creative capital, but still may catch up if local development delivers positive results. The remaining 15 communities are almost devoid of a creative class. Many of them face severe economic troubles and urgently need to reinvent themselves in order to survive. Unfortunately, such a change of trajectory does not seem likely from the results discussed here.

To further explore the typological differences across the sample of communities, I employed a cluster analysis. The task was to determine whether northern towns could be sorted into several distinct groups on the basis of their individual creative class characteristics (TI, BI, LI, EI, and ASI) and controlling for the population size. Clustering reveals five groups of communities (Fig. 1). The group with 
the strongest creative class includes the creative hot spots (Whitehorse, Yellowknife, Smithers, Inuvik, and Fort Smith) that show high scores in all measures. Iqaluit and Rankin Inlet form their own cluster, which may be called the aboriginal creative towns. They have strong bohemian, leadership, and entrepreneurship components of the creative class, but are weaker in terms of formal education and technical occupations. Another three groups represent different types of industrial towns: a group of larger cities with modest creative capital (Baie-Comeau, ChicoutimiJonquière, Fort McMurray, Prince George, Sault Ste. Marie, Slave Lake, Thunder Bay, Rouyn-Noranda, Timmins, and Happy Valley-Goose Bay), and two groups of progressively smaller single-industry towns with a weak or very weak creative class (all other communities).

Since the results discussed so far strongly suggest that quality of place exerts an influence on the creative class, the attractiveness ranking was also performed (Table 5). The same communities that already had a relatively large creative class occupy the first five places: Whitehorse, Inuvik, Yellowknife, Rankin Inlet, and Iqaluit. The ranking demonstrates once more the uneven distribution of creativity potential in the North, which has several stable centres that have potential to attract the creative class. The high position of Inuvik and Rankin Inlet appears to be remarkable (since they are not capitals) and deserves further inquiry.

Both creative class and attractiveness indicators reveal the advantage of territorial capitals. Their thriving public sector creates high-skilled, well-paid jobs and a dynamic social environment, desirable to the creative class. Industrial towns like Fort McMurray and Baie-Comeau, on the other hand, score relatively high in creativity measures based on technical occupations, but have a low profile in other measures. In contrast, aboriginal communities usually have good standing on bohemian, leadership, and (sometimes) entrepreneurship indices, but perform poorly in terms of technical occupations and residents' education.

\section{Potential Policy Implications}

What do the results of this research mean for regional development in the North? Traditionally, regional development policies for the North have targeted primary manufacturing, local services, and tourism (de la Barre, 1987), whereas the approach to planning and implementation was strictly top-down (Ironside, 2000). Only since the late 1980s has the real economic value of education and culture finally been recognized so that bottom-up development efforts have come to be appreciated (SCONE, 1989). However, creating opportunities for people to receive and use educational, leadership, and entrepreneurial competencies has rarely been considered a primary policy effort.

Northern artists are a case in point: they earn considerably lower wages than do their counterparts in other parts of Canada (Hill Strategies, 2004). Consequently, a northern artisan industry cannot fully realize its economic potential and become a major driver of economic development. The current weakness likely arises from a lack of entrepreneurial opportunities, poor business management practices, and inadequate infrastructure for marketing local arts and crafts. The promotion of the cultural economy may not only provide an additional source of income, but also strengthen the northern labor force by attracting nonparticipants, especially Native women.

If the results of this analysis are further confirmed, one may argue that more attention should be given to developing creative economies, "soft" infrastructure, and creative human capital. Some of these activities will be linked to staples or to the public sector; others will rely on the cultural and environmental uniqueness of the North, or on local industries. Arguably, there is a need for a policy shift, most particularly in selected leading communities, to ensure that education, business skills, leadership abilities, and artistic talents develop simultaneously. Such development is likely to stimulate economic growth if pursued thoroughly through bottom-up, community-based approaches (Ross and Usher, 1986; Ironside, 2000). However, I agree with Bollman (1999:27) that human creative capital is a "necessary, but not sufficient condition" of economic growth in peripheral areas, and that nurturing the creative class will not automatically deliver positive results unless complemented by other development incentives.

\section{CONCLUSION}

This alternative perspective on regional development in the Canadian North has drawn on the concept of the creative class and creative economies. The creative class is an important factor of economic transformation in the periphery as it is in other regions. This first-cut empirical analysis indicates that if Florida's methodology and theory are to be applied to the Canadian North, they must be adjusted to the regional specifics. This is especially true because the creative class plays a unique role in the periphery (as agents of transformation, not merely producers of knowledge and high-end consumers). Thus Florida's metropolitan policy prescriptions, taken uncritically, are unlikely to be fruitful in peripheral settings. However, non-metropolitan communities can find alternative ways to compete for creative capital and benefit from it (Scott, 2006).

The first major conclusion of this exploratory analysis is that both the overall potential and the degree of development of the creative class in the Canadian North are low. The northern creative class is also less formally educated and lacks entrepreneurial capacities. In terms of attracting creativity, northern communities also face formidable challenges in competition with the rest of the country. However, a few places can compete for the creative class countrywide, most prominently Whitehorse and Yellowknife (and possibly Inuvik, Rankin Inlet, and Iqaluit).

The second main conclusion is that the six leading communities that scored high in all creative class indices 
-Yellowknife, Whitehorse, Iqaluit, Inuvik, Fort Smith, and Smithers-represent the creative core of the North. In these places the creative potential is high, and here the efforts of developing a new economic trajectory would perhaps be most fruitful. The analysis also revealed the systematic differences among communities, likely linked to their size, economic specialization, and population composition. Interestingly, the more southerly towns tend to have a weaker creative class than some more distant and remote communities.

By design, this study is exploratory. The analysis started in this paper should be followed by a more exhaustive inquiry, possibly involving a greater number of communities, more elaborate measures of innovative and technological activity, more detailed occupational data, and most importantly, qualitative methods. There is more to learn regarding the role of distance or proximity to southern creative centres and the importance of push-factors (such as harsh environment, housing problems, and isolation) as well as pull-factors in attracting the creative class. Future research must also address unintended external effects of creative economies, such as socioeconomic inequality, lack of affordable housing, negative environmental impacts, and political polarization.

\section{ACKNOWLEDGEMENTS}

The author is grateful to Meric S. Gertler, Richard J. DiFrancesco, three reviewers and the editor for their valuable comments on earlier drafts of this paper.

\section{REFERENCES}

AARS ÆTHER, N., ed. 2004. Innovations in the Nordic periphery. Stockholm: Nordregio.

AMIN, S. 2001. Imperialism and globalization. Monthly Review 53(2):6-24.

ANDERSSON, A. 1985. Creativity and regional development. Papers in Regional Science 56:5 - 20, doi10.1007/BF01887900.

ARTHUR, W.B. 1996. Increasing returns and the new world of business. Harvard Business Review 74(4):100-109.

BASSANINI, A.P., and DOSI, G. 2001. When and how chance and human will can twist the arms of Clio. In: Garud, R., and Karnoe, P., eds. Path dependence and creation. Mahwah, New York: Lawrence Erlbaum. 41-68.

BATHELT, H., and BOGGS, J. 2005. Continuities, ruptures, and re-bundling of regional development paths: Leipzig's metamorphosis. In: Fuchs, G., and Shapira, P., eds. Rethinking regional innovation and change: Path dependency or regional breakthrough? New York: Springer. 147-170.

BATHELT, H., and GLUCKER, J. 2003. Toward a relational economic geography. Journal of Economic Geography 3:117-144.

BOLLMAN, R.D. 1999. Human capital and rural development: What are the linkages? Working Paper \#39. Ottawa: Agriculture Division, Statistics Canada.
BONE, R.M. 2003. The geography of the Canadian North: Issues and challenges. 2nd ed. Toronto: Oxford University Press.

BONE, R.M., and GREEN, M. 1984. The northern Native labor force: A disadvantaged work force. Operational Geographer 3:12-14.

CLARK, P., TRACEY, P., and LAWTON SMITH, H. 2001. Agents, endowments, and path-dependence: A model of multijurisdictional regional development. Geographische Zeitschrift 89:166-181.

DE LA BARRE, K. 1987. Strategies in northern development in Canada since the late 1960s. Acta Borealia 1-2:91-118.

DESROCHERS, P. 2001. Local diversity, human creativity, and technological innovation. Growth and Change 32:369-394.

FCM(FEDERATION OFCANADIAN MUNICIPALITIES). 2002. Bridging the innovation gap: Count cities in. Ottawa: FCM.

FERRUCCI, L., and PORCHEDDU, D. 2006. An emerging ICT cluster in a marginal region: The Sardinian experience. In: Cooke, P., and Piccaluga, A., eds. Regional development in the knowledge economy. London and New York: Routledge. $203-226$.

FLORIDA, R. 2002a. The economic geography of talent. Annals of the Association of American Geographers 94(2):743-755.

- 2002b. The rise of the creative class. New York: Basic Books.

- 2005. Cities and the creative class. New York: Routledge.

FLORIDA, R., and GATES, G. 2001. Technology and tolerance: The importance of diversity to high-technology growth. Washington, D.C.: Center on Urban and Metropolitan Policy, The Brookings Institution.

FRIEDMANN, J. 1966. Regional development policy: A case study of Venezuela. Cambridge, Massachusetts: The MIT Press.

. 1996. Introduction: Borders, margins and frontiers: Myth and metaphor. In: Gradus, Y., and Lithwick, H., eds. Frontiers in regional development. Lanham, Maryland: Rowman \& Littefield. 1-20.

GERTLER, M.S. 2005. Tacit knowledge, path dependency and local trajectories of growth. In: Fuchs, G., and Shapira, P. eds. Rethinking regional innovation and change. Path dependency or regional breakthrough? New York: Springer. 23-42.

GERTLER, M.S., FLORIDA, R., GATES, G., and VINODRAI, T. 2002. Competing on creativity: Placing Ontario's cities in the North American context. Toronto: Institute of Competitiveness and Prosperity and the Ontario Ministry of Enterprise, Opportunity and Innovation.

GLAESER, E.L. 2000. The new economics of urban regional growth. In: Clark, G.L., Feldman, M.P., and Gertler, M.S., eds. The Oxford handbook of economic geography. Oxford: Oxford University Press. 83-98.

- 2005. Review of Richard Florida's "The rise of the creative class." Regional Science and Urban Economics 35(5): $593-596$.

GRABHER, G. 1993. The weakness of strong ties: The lock-in of regional development in the Ruhr Area. In: Grabher, G., ed. The embedded firm: On the socio-economics of industrial networks. London: Routledge. 255-277.

HAMELIN, L.-E. 1975. Nordicity canadienne. Montreal: Hurtubise HM. 
HANSON, G.H. 2000. Firms, workers, and the geographic concentration of economic activity. In: Clark, G.L., Feldman, M.P., and Gertler, M.S., eds. The Oxford handbook of economic geography. Oxford: Oxford University Press. 477-494.

HAYTER, R., BARNES, T., and GRASS, E. 1994. Single industry towns and local development: Three coastal British Columbia forest product communities. Research Report No. 34. Thunder Bay, Ontario: Lakehead University Centre for Northern Studies.

HILL STRATEGIES. 2004. Artists in Canada's provinces, territories and metropolitan areas. A report funded by the Canada Council for the Arts, the Department of Canadian Heritage, and the Ontario Arts Council. Toronto: Hill Strategies Research Inc.

HULL, J. 2000. Aboriginal post-secondary education and labour market outcomes: Canada, 1996. Ottawa: Data Strategic Research Directorate, Indian and Northern Affairs Canada.

HUMAN RESOURCES AND SOCIAL DEVELOPMENT CANADA. 2008. National occupational classification. Ottawa: HRSDC. http://www5.hrsdc.gc.ca/NOC-CNP/app/index.aspx? lc $=\mathrm{E}$.

INNIS, H. 1956. The fur trade in Canada: An introduction to Canadian economic history. Toronto: University of Toronto Press.

IRONSIDE, R.G. 2000. Canadian northern settlements: Top-down and bottom-up influences. Geografisca Annaler 820B(2): $103-114$.

JACOBS, J. 1984. Cities and the wealth of nations. New York: Random House.

KERR, D., MOYSER, M., and BEAUJOT, R. 2006. Marriage and cohabitation: Demographic and socioeconomic differences in Québec and Canada. Canadian Studies in Population 33(1): 83-117.

LUNDVALL, B.-Å., ed. 1992. National systems of innovation: Towards a theory of innovation and interactive learning. London: Pinter Publishers.

MARKUSEN, A. 2006. Urban development and the politics of a creative class: Evidence from a study of artists. Environment and Planning A 38(10):1921-1940.

McGRANAHAN, D., and WOJAN, T. 2007. Recasting the creative class to examine growth processes in rural and urban counties. Regional Studies 41(2):197-216.

McNIVEN, C., and PUDERER, H. 2000. Delineation of Canada's North: An examination of the North-South relationship in Canada. Geography Working Paper Series 2000-3. Ottawa: Geography Division, Statistics Canada. http://www.statcan.ca/cgi-bin/ downpub/listpub.cgi?catno=92F0138MIE2000003. 23 p.
MORGAN, K. 1997. The learning region: Institutions, innovation and regional renewal. Regional Studies 31(5):491-503.

NAICS (NORTH AMERICAN INDUSTRY CLASSIFICATION SYSTEM). 2007. NAICS-United States 2007 manual. Washington, D.C.: U.S. Census Bureau.

NORTH, D., and SMALLBONE, D. 2000: Innovative activity in SMEs and rural economic development: Some evidence from England. European Planning Studies 8:87-106.

OTTAVIANO, G.I.P., and PERI, G. 2006. The economic value of cultural diversity: Evidence from US cities. Journal of Economic Geography 6(1):9-44.

PECK, J. 2005. Struggling with the creative class. International Journal of Urban and Rural Research 29(4):740-770.

PORTER, M. 1998. Clusters and the new economics of competition. Harvard Business Review 76(6):77-90.

ROMER, P.M. 1990. Endogenous technological change. Journal of Political Economy 98(5):71-102.

ROSS, D.P., and USHER, P.J. 1986. From roots up: Economic development as if community mattered. Croton-on-Hudson, New York: The Bootstrap Press.

SARKAR, P. 1994. Terms of trade of the South vis-a-vis the North: A macroeconomic framework. In: Sapsford, D., Morgan, W., and Morgan, C.W., eds. The economics of primary commodities: Models, analysis and policy. Brookfield, Vermont: Edward Elgar. 79-90.

SCHIENSTOCK, G. 2007. From path dependency to path creation: Finland on its way to the knowledge-based economy. Current Sociology 55(1):92-109.

SCONE (SPECIAL COMMITTEE ON THE NORTHERN ECONOMY). 1989. The Scone Report: Building our economic future. Yellowknife: Legislative Assembly of the Northwest Territories.

SCOTT, A.J. 2006. Creative cities: Conceptual issues and policy questions. Journal of Urban Affairs 28(1):1-17.

SHEARMUR, R. 2007. The new knowledge aristocracy: A few thoughts on the creative class, mobility and urban growth. Work, Organization, Labor and Globalization 1(1):31-47.

SIMON, C.J., and NARDINELLI, C. 2002. Human capital and the rise of American cities, 1900-1990. Regional Science and Urban Economics 32(1):59-96.

STATISTICS CANADA. 2002. 2001 community profiles. http:// www.12statcan.ca/english/profil01/CP01/Index.cfm2Lang=E.

ZACHARY, G.P. 2000. The global me: New cosmopolitans and the competitive edge: Picking globalism's winners and losers. New York: PublicAffairs, Perseus Books Group. 